\title{
Consequences of sea level variability and sea level rise for Cuban territory
}

\author{
MARCELINO HERNÁNDEZ1 ${ }^{1}$, CARLOS A. MARTÍNEZ ${ }^{1}$ \& ORLANDO MARZO² \\ 1 Institute of Oceanology, 18406 1st Avenue, Flores, Playa, Havana, Cuba \\ marcel@oceano.inf.cu \\ 2 National Tide Gauge Network, Geocuba Geodesia, Loma and 39, Plaza, Havana, Cuba
}

\begin{abstract}
The objective of the present paper was to determine a first approximation of coastal zone flooding by 2100 , taking into account the more persistent processes of sea level variability and non-accelerated linear sea level rise estimation to assess the main impacts. The annual linear rate of mean sea level rise in the Cuban archipelago, obtained from the longest tide gauge records, has fluctuated between $0.005 \mathrm{~cm} / \mathrm{year}$ at Casilda and $0.214 \mathrm{~cm} /$ year at Siboney. The main sea level rise effects for the Cuban coastal zone due to climate change and global warming are shown. Monthly and annual mean sea level anomalies, some of which are similar to or higher than the mean sea level rise estimated for halfway through the present century, reinforce the inland seawater penetration due to the semi-daily high tide. The combination of these different events will result in the loss of goods and services, and require expensive investments for adaption.
\end{abstract}

Key words sea level rise; flooding; climate change; global warming; tides; climate change; tide gauge; global warming; coast; Cuba

\section{INTRODUCTION}

The Cuban archipelago extends from east to west between the Gulf of Mexico, Florida Straits and the canals of St. Nicholas and Old Bahamas to the north; the western Caribbean Sea and Columbus Strait to the south, and the Yucatan Channel and Windward Passage to the west and east, respectively. It is located between latitudes $19^{\circ} 49^{\prime} 36^{\prime \prime}$ and $23^{\circ} 17^{\prime} 09^{\prime \prime}$ north, and longitudes $74^{\circ} 07^{\prime} 52^{\prime \prime}$ and $84^{\circ} 54^{\prime} 57^{\prime \prime}$ west. The Island of Cuba is long and narrow, with $1250 \mathrm{~km}$ from Cabo de San Antonio at the western end, to the easternmost point, Punta Maisí. The maximum width is $191 \mathrm{~km}$ and the minimum only $31 \mathrm{~km}$. The archipelago consists of the Island of Cuba, the Isle of Youth, and more than 1600 islands, islets and keys, amounting to a total surface area of about $110922 \mathrm{~km}^{2}$. An area of approx. $105007 \mathrm{~km}^{2}$ corresponds to the Island of Cuba, and $2200 \mathrm{~km}^{2}$ to the Isle of Youth. The remaining keys and islets cover $3715 \mathrm{~km}^{2}$, while the insular shelf spans $67832 \mathrm{~km}^{2}$ (Furrazola and Nuñez, 1997). There are four types of coast: iron-shore low terrace, mangrove swamps, beaches and coastal cliffs (Toledo et al., 2005), with four corresponding shelf areas, separated by coastal sectors where the shelf edge is close to the coast.

Sea level rise has been identified as the main threat to the Cuban archipelago (Centella et al., 2001; Hernández-González et al., 2012). The objective of the present paper was to determine the first approximation of possible coastal zone flooding by 2100 , taking into account the more persistent processes of sea level variability and non-accelerated linear sea level rise estimation to assess the main impacts, from direct measurements at 39 temporary and permanent tide gauges of the National Tide Gauge Network and from a geographic information system.

\section{DATA AND METHODS}

Sea level hourly height time series from 38 permanent and temporary tide gauges of the National Tide Gauge Network plus Guantanamo tide gauge were used as primary information (Fig. 1 and Table 1). The National Tide Gauge Network was created in 1966, and its measurements and analysis are governed by a unique documented methodology (Geocuba Geodesia, 2004) that takes into account international standards (IOC, 2006). Equipment used for measurements have the characteristics recommended by the Intergovernmental Oceanographic Commission (HernándezGonzález et al., 2010). Monthly and annual mean values from six Cuban tide gauges are sent to GLOSS. 
Table 1 Characteristics of hourly data series and flooding estimation.

\begin{tabular}{|c|c|c|c|c|c|c|c|}
\hline Tide gauges & Latitude & Longitude & $\begin{array}{l}\text { Date } \\
\text { From - To }\end{array}$ & $\begin{array}{l}\text { HAT \& } \\
(\mathrm{Sa}+\mathrm{Ssa}) \\
(\mathrm{cm})\end{array}$ & $\begin{array}{l}\mathrm{HAT}+ \\
\text { MSLA } \\
(\mathrm{cm})\end{array}$ & $\begin{array}{l}\text { Perm. } \\
\text { flooding } \\
(\mathrm{cm})\end{array}$ & $\begin{array}{l}\text { Flooding } \\
\text { by } 2100 \\
(\mathrm{~cm})\end{array}$ \\
\hline Los Morros & 2154,0 & 8454,4 & $1971-2012$ & 22 & 59 & 5 & 64 \\
\hline La Fé & 2202,5 & 8416,5 & 1971 & 33 & 70 & 33 & 103 \\
\hline Los Arroyos & 2221,1 & 8422,8 & 1971 & 41 & 78 & 33 & 111 \\
\hline Santa Lucía & 2240,5 & 8358,0 & 1971 & 40 & 77 & 33 & 110 \\
\hline Bahía Honda & 2256,1 & 8311,1 & 1971 & 32 & 69 & 33 & 102 \\
\hline Cabañas & 2259,4 & 8258,6 & 1971 & 32 & 69 & 33 & 102 \\
\hline Mariel & 2301,2 & 8245,4 & 2001-2012 & 45 & 82 & 33 & 115 \\
\hline Siboney & 2305,5 & 8228,5 & 1966-2005 & 34 & 71 & 33 & 104 \\
\hline La Habana & 2308,9 & 8221,2 & $1970-2012$ & 37 & 74 & 33 & 107 \\
\hline Matanzas & 2303,5 & 8133,2 & 1973 & 37 & 74 & 33 & 107 \\
\hline Punta Hicacos & 2311,6 & 8107,6 & $1971-1972$ & 33 & 70 & 33 & 103 \\
\hline La Isabela & 2256,4 & 8000,8 & 1973-2012 & 30 & 67 & 12 & 79 \\
\hline Cayo Francés & 2238,5 & 7914,0 & 1972 & 42 & 79 & 12 & 91 \\
\hline Bufadero & 2133,6 & 7714,2 & 1992-2008 & 37 & 74 & 12 & 86 \\
\hline Punta de Prácticos & 2136,2 & 7705,9 & $1992-2012$ & 47 & 84 & 12 & 96 \\
\hline Manatí & 2121,4 & 7649,5 & 1971-1972 & 68 & 105 & 23 & 128 \\
\hline Puerto Padre & 2112,1 & 7636,0 & 2001 & 40 & 77 & 23 & 100 \\
\hline Gibara & 2106,5 & 7607,5 & 1976-2012 & 42 & 79 & 23 & 102 \\
\hline Banes & 2055,1 & 7542,4 & $2002-2005$ & 55 & 92 & 23 & 115 \\
\hline Preston & 2046,0 & 7539,4 & 1972 & 41 & 78 & 23 & 101 \\
\hline Saetía & 2046,6 & 7534,7 & 1972 & 70 & 107 & 23 & 130 \\
\hline Levisa & 2042,9 & 7533,0 & 1972 & 70 & 107 & 23 & 130 \\
\hline Tánamo & 2040,7 & 7520,1 & 1972 & 62 & 99 & 23 & 122 \\
\hline Moa & 2039,2 & 7454,6 & 1989-1990 & 63 & 100 & 23 & 123 \\
\hline Baracoa & 2021,1 & 7430,1 & $1973-1978$ & 62 & 99 & 23 & 122 \\
\hline Maisí & 2014,8 & 7408,7 & 1995 & 56 & 93 & 23 & 116 \\
\hline Guantánamo & 1953,6 & 7509,9 & 1937-1971 & 34 & 64 & 12 & 76 \\
\hline Santiago de Cuba & 1959,1 & 7552,5 & 1992 & 27 & 62 & 12 & 74 \\
\hline Pilón & 1954,0 & 7719,1 & 1972 & 25 & 57 & 12 & 69 \\
\hline Cabo Cruz & 1950,4 & 7743,7 & 1992-2012 & 20 & 82 & 12 & 94 \\
\hline Manzanillo & 2020,4 & 7708,8 & 1992-2012 & 45 & 77 & 12 & 89 \\
\hline Santa Cruz del Sur & 2042,0 & 7758,6 & 1994-2001 & 40 & 61 & 12 & 73 \\
\hline Casilda & 2145,2 & 7959,5 & $1972-2012$ & 24 & 54 & 12 & 66 \\
\hline Punta Los Colorados & 2202,0 & 8026,6 & 1971 & 17 & 57 & 12 & 69 \\
\hline Cayo Loco & 2209,1 & 8027,3 & $1992-2012$ & 20 & 56 & 12 & 68 \\
\hline Playa Girón & 2203,9 & 8102,2 & 1971 & 19 & 59 & 12 & 71 \\
\hline Cayo Largo & 2137,3 & 8133,9 & 1983-1984 & 22 & 57 & 12 & 69 \\
\hline Carapachibey & 2126,9 & 8255,3 & 1977 & 20 & 56 & 12 & 68 \\
\hline La Coloma & 2214,2 & 8334,3 & 1991-2001 & 19 & 37 & 12 & 49 \\
\hline
\end{tabular}

Perm. flooding, value of relative mean sea level increase by 2100; MSLA, the highest monthly mean sea level anomaly; HAT \& ( $\mathrm{Sa}+\mathrm{Ssa})$, the value of the highest astronomical tide that includes sea level seasonal variations; Flooding by 2100 , sea level flooding by 2100 .

Bathymetry and altimetry data were obtained from the GEBCO System (General Bathymetric Chart of the Oceans) available on the Internet at: http://www.gebco.net/ data and products/gridded_bathymetry_data/, and SRTM v. 4: http://www.cigar.gov, using the WGS84, EPSG: 4236. To develop the layer that represents the flooding of low lying areas by 2100, GIS Mapinfo 10.5 and Discover 12 were used, following the same steps as those used to obtain the layers corresponding to the bathymetric and altimetric data, and to socio-economic and ecological information (human settlements, roads, industries, agricultural and forest areas, and other). 


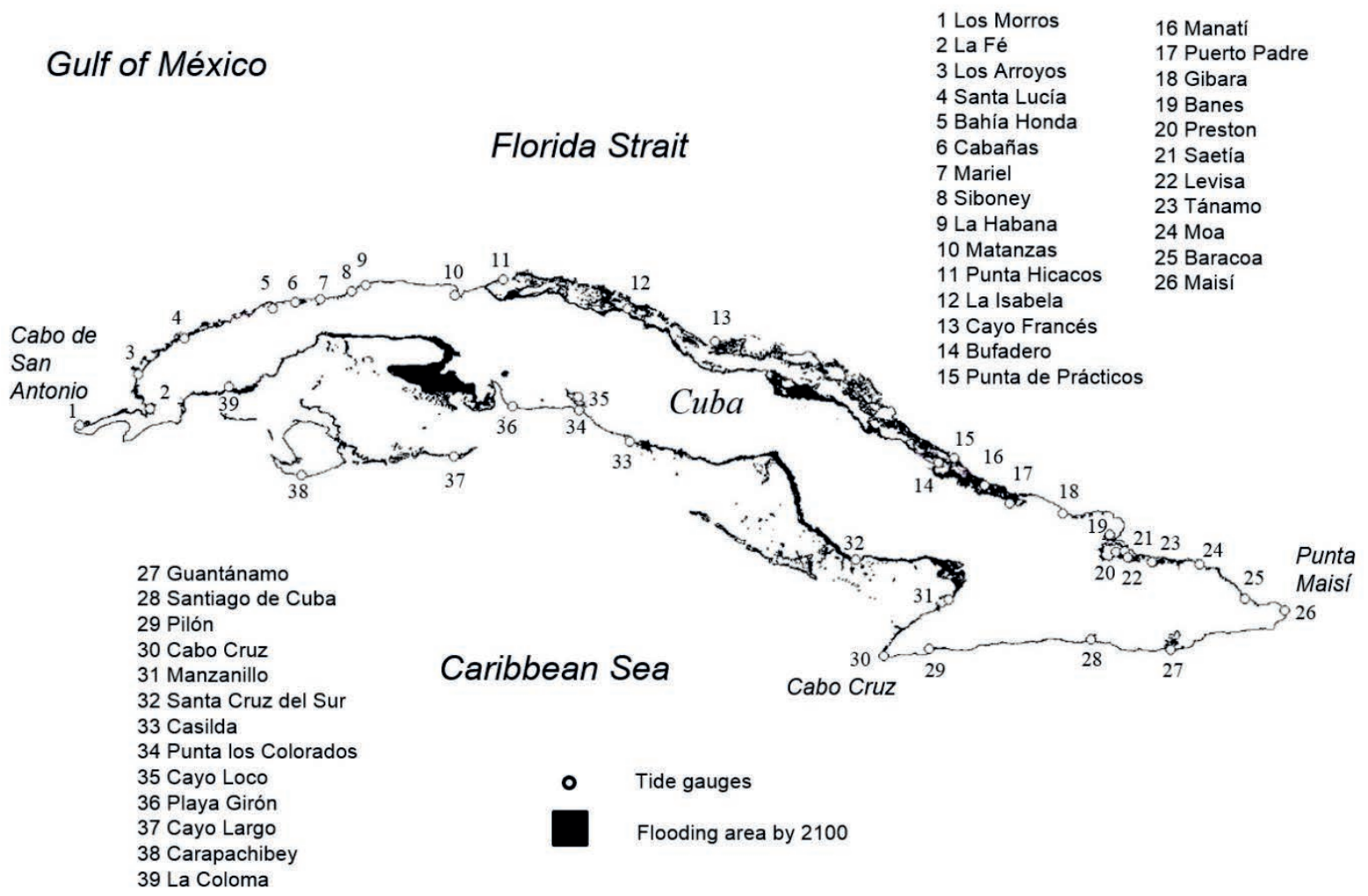

Fig. 1 Geographical distribution of tide gauges and estimated sea level flooding by 2100 .

\section{Sea level rise calculation}

Restitution of absent data in the series of observed sea level hourly heights, the calculation of annual mean values and of trend, estimated as a linear adjustment of the annual mean values from a first grade linear equation, were performed according to Hernández-González et al. (2010). The calculation of the annual linear rate of relative mean sea level was done from the tide gauges with longer measurements: Los Morros, Siboney, La Isabela, Gibara and Casilda (Table 1). The annual mean value series of tide gauges from Guantanamo to La Coloma were averaged, because trends are very mild or almost null on the southern coast of Cuba, especially in the longest data series (Hernández-González et al., 2010), and taking into account the existence of a high linear correlation between monthly mean value series and the determination coefficient values, $R$ between 0.76 and 0.90 (Hernández-González and Marzo, 2009). From the new series obtained, a single annual linear rate for the entire south coast was calculated. Then, five values of the annual linear rate of relative mean sea level were calculated, and with these, the values of relative mean sea level increase by 2100 (Table 2 ).

Sea level flooding by 2100 (Flooding area by 2100) was calculated as the sum of permanent flooding, represented by the value of relative mean sea level increase by 2100 (Perm. flooding), the highest monthly mean sea level anomaly (MSLA), and the value of the highest astronomical tide that includes sea level seasonal variations (HAT \& Sa $+\mathrm{Ssa}$ ) (see Table 1).

Table 2 Application of relative mean sea level value and increase per Cuban coastal sectors by 2100.

\begin{tabular}{lllc}
\hline & Reference tide gauge & Coastal sector & Perm. flooding \\
\hline 1 & Los Morros & Cabo de San Antonio & $5.43 \mathrm{~cm}$ \\
2 & Siboney & Cabo de San Antonio - Cárdenas & $33.40 \mathrm{~cm}$ \\
3 & La Isabela & Cárdenas - Punta de Prácticos & $11.99 \mathrm{~cm}$ \\
4 & Gibara & Punta de Prácticos - Punta Maisí & $22.70 \mathrm{~cm}$ \\
5 & Average for south coast & South coast of Cuba & $12.12 \mathrm{~cm}$ \\
\hline
\end{tabular}


The linear increase in relative mean sea level by 2100 (Perm. flooding) was applied to the coastal sectors of Cuban territory according to Table 2.

\section{RESULTS}

\section{Astronomical tides}

Mixed semi-diurnal tide prevails in Cuban waters, except for some small coastal sectors where diurnal and mixed-diurnal tides occur. Tide mean amplitude varies between less than $25 \mathrm{~cm}$ and $65 \mathrm{~cm}$, and is bigger on the north coast than on the south (Rodríguez and Rodríguez, 1983). For the present work, the highest astronomical tide (HAT) values were used, according to the updated information reported annually for each tide gauge (SHG, 2012).

\section{Annual mean cycle and monthly anomalies}

The maximum values of the sea level annual mean cycle (AMC) are located between September and October, and the minimum values between January and March (Hernández-González and Marzo, 2009). Long-term solar annual (Sa) and solar semi-annual (Ssa) components determine the seasonal variability, with values comparable to those of the main semi-diurnal lunar wave, $\mathrm{M}_{2}$. For this reason, the resultant of the $\mathrm{Sa}+\mathrm{Ssa}$ component at each tide gauge was added to HAT values, according to the updated information reported annually by the Hydrographic and Geodetic Service (SHG, 2012).

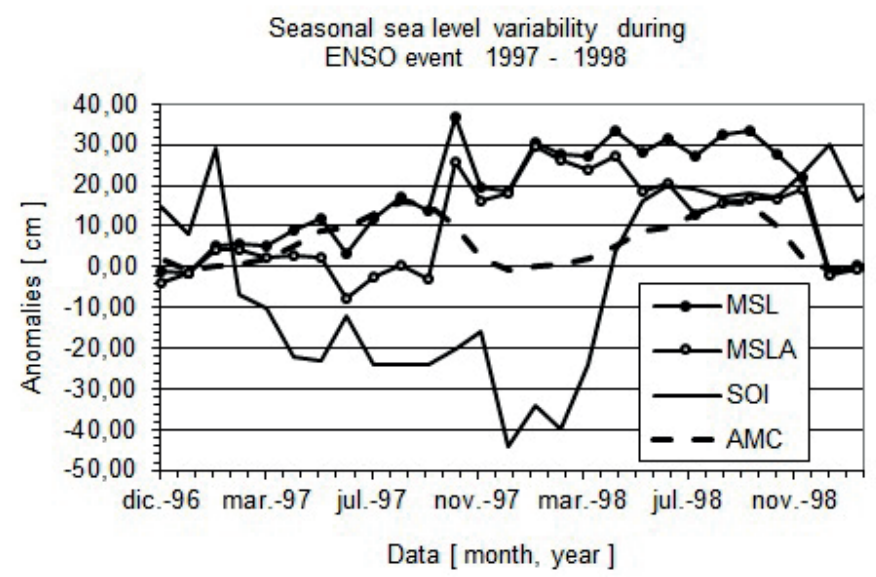

Fig. 2 Sea level monthly anomalies. MSL - monthly sea level; MSLA - monthly sea level anomalies; SOI - Southern Oscillation Index; AMC - annual mean cycle.

It has been proven that remarkable positive anomalies of monthly and annual mean sea level are recorded during ENSO events in all Cuban tide gauges (Fig. 2), with important alterations of annual mean sea level cycle during one year and more (Blázquez, 1989; Hernández-González \& Díaz-Llanes, 2001; Hernández-González and Marzo, 2009; Hernández-González et al., 2012). Some of the monthly mean sea levels recorded are comparable in magnitude with some of the estimates of the relative mean sea level increment for halfway through the present century because of climate change. Therefore, these extreme monthly levels were taken into account when mapping floods by long-term mean sea level rise. In the present work, the monthly mean sea level of $36.8 \mathrm{~cm}$ recorded at La Isabela tide gauge in November 1997 (Fig. 2) was used.

\section{The annual linear rate of relative mean sea level in the Cuban archipelago}

The highest value in the annual linear rate of relative mean sea level was obtained at Siboney $(2.14 \mathrm{~mm} /$ year $)$ on the coast of Havana, and the lowest at Casilda $(0.05 \mathrm{~mm} /$ year $)$ on the south coast of Cuba. Los Morros $(0.37 \mathrm{~mm} /$ year), and La Isabela $(0.34 \mathrm{~mm} /$ year $)$ only showed a slight linear trend to increase. 


\section{Sea level flooding by 2100 and consequences}

According to these results, the total flooded area would be $8.24 \%$ of Cuban territory (Fig. 1; Table 1 ), assuming that all or most of the keys and islands will be flooded or seriously affected. Most of the flooded areas coincide mainly with mangrove swamps on the south and northeastern coasts of Cuba. Mangrove swamps, of great economic and ecological importance, occupy $4.8 \%$ of the Cuban land area. Since they are open ecosystems, with a constant flow of matter and energy, they will exercise a strong influence on the adjacent land and sea ecosystems (Leda and Guzmán, 2002).

Ecological and human settlement studies foresee that keys and islands of the archipelago will be lost. Marshes occupied by mangrove forest formations and grasslands will be affected, as well as low coastal areas, river deltas, tidelands and sandy dunes on the beaches. A permanent flood of approximately $30 \mathrm{~cm}$ would affect more than 70 coastal settlements and cause the disappearance of 15 of them. Seawater intrusion in rivers and aquifers will increase. This process will cause subsequent salinization of agricultural land, mainly in the dry season. Therefore, it is considered more viable to relocate towns and economic activities (Rodríguez et al., 2010; Planos et al., 2012). The more evident consequences of relative mean sea level increase for the Cuban archipelago are:

- Gradual increase in submerged areas at the expense of emerged areas.

- Gradual increase in the median plane of monthly and annual mean sea level anomalies.

- Seawater intrusion in rivers and aquifers will increase.

- Gradual increase in coastal flooding.

- Need for costly investments in coastal protection structures and relocation of human settlements.

\section{CONCLUSIONS}

- The annual linear sea level rise rate in the Cuban archipelago, obtained from the longest tide gauge records, fluctuated between $0.214 \mathrm{~cm} /$ year at Siboney and $0.005 \mathrm{~cm} /$ year at Casilda.

- Monthly and annual anomalies of mean sea level, some of which are similar to or higher than the mean sea level rise estimated for halfway through the present century, reinforce the inland penetration of seawater due to the semi-daily tide run-up.

- The total flooded area would be $8.24 \%$ of Cuban territory.

- The combination of these different events will result in the loss of goods and services, causing expensive investments for adaption.

Acknowledgements This work was sponsored by the research project "Estimation of the anomalies, trend, projection and return periods of relative mean sea level and extreme values during the present century, from measurements of the National Tide Gauge Network", being developed at the Cuban Institute of Oceanology. The authors wish to express special thanks for their support to Dr Erlend Moksness, Research Director at the Norwegian Institute of Marine Research; Dr Thorkild Aarup, Senior Programme Specialist of the Intergovernmental Oceanographic Commission, and Mrs Martha M. Rivero Fernández, head of the Marine Information Service at the Institute of Oceanology.

\section{REFERENCES}

Blázquez, E. L. (1989) Anomalías del Nivel del Mar en La Habana, Cuba, durante el evento Oscilación del Sur - El Niño (OSEN), de 1982-83. Reporte de Investigación 6, 11.

Centella A., et al. (2001) Primera Comunicación Nacional a la Convención Marco de las Naciones Unidas sobre Cambio Climático. Grupo Nacional de Cambio Climático. Instituto de Meteorología. Cubaenergia, 169.

Furrazola, G. and Núñez, K. (1997) Estudios sobre Geología de Cuba. La Habana, CNDIG, 527.

Geocuba Geodesia (2004) MET 30-34. Geocuba Geodesia Archive, 42.

Hernández-González, M., Marzo, O. and Acanda, A. (2010) Tendencia lineal del nivel medio del mar en algunas localidades del archipiélago cubano. Serie Oceanológica 7, 1-15. ISSN: 2072-800X. http://oceanologia.redciencia.cu. 
Hernández-González, M., et al. (2012) Estimación de las anomalías, tendencia, proyección y los períodos de retorno de los valores extremos del nivel del mar relativo durante el presente siglo a partir de mediciones de la Red Mareográfica Nacional. Informe anual de proyecto. Institute of Oceanology Archive, 153.

Hernández-González, M. and Marzo, O. (2009) Variabilidad estacional del nivel del mar en el archipiélago cubano. Serie Oceanológica 6, 1-15. ISSN: 2072-800X. Available from: http://oceanologia.redciencia.cu.

Hernández-González, M. and Díaz-Llanes, G. (2001a) Influences of ENSO on seasonal and inter-annual sea level variability in the Cuban Archipelago. Serie Oceanológica, ISSN: 2072-800X. Available from: http://oceanologia.redciencia.cu.

IOC (2006) Manual on Sea Level Measurement and Interpretation. Vol. 4 - An Update to 2006. Ed. by T. Aaurup, et al., Intergovernmental Oceanographic. Commission Manuals and Guides 14 (IV), París, 80.

Leda, M. and Guzmán, J.M. (2002) Ecosistemas de manglar del archipiélago cubano. Editorial Academia. 465.

Planos, E., Rivero, R. and Guevara, V. (2012) Impacto del cambio climático y medidas de adaptación en Cuba. La Habana. $A M A, 520$.

Rodríguez, J.P. and Rodríguez, J.F. (1983) Las mareas en las costas cubanas. Reporte de Investigación, 6, 34.

Rodríguez, C., Favier L. and Boquet A. (2010) Evaluación del impacto y vulnerabilidad de los asentamientos costeros por efecto del cambio climático y eventos meteorológicos extremos para los años 2050 y 2100 . Versión III mapa de Alerta Temprana. Informe técnico. Instituto de Planificación Física, 84.

SHG (2012) Tablas de marea de las costas de Cuba. Servicio Hidrográfico y Geodésico de la República de Cuba, La Habana, Edimar, 248.

Toledo, M., et al. (2005) Características geólogo - geomorfológicas de las costas cubanas. Incidencia en la vulnerabilidad de éstas y su dinámica litoral. La Habana, Sociedad Cubana de Geología, 12. 